\title{
The concept of HPWS-Performance relationship: Framework for Education Industry
}

\author{
Osman Sadiq Paracha ${ }^{1}$, Wan Khairuzzaman Wan Ismail ${ }^{2}$, Salmiah Mohamad Amin $^{3}$ \\ ${ }^{1}$ Comsats Institute of Information Technology (Pakistan) \\ ${ }^{2}$ Jazan University (Saudi Arabia) \\ ${ }^{3}$ Universiti Teknologi Malaysia (Malaysia) \\ osman.paracha@yahoo.com,.mwkhair@ibs.utm.my,salmiah@utm.my
}

Received September, 2012

Accepted February, 2014

\section{Abstract}

Purpose: The purpose of this paper is to enhance the knowledge of High Performance Work Systems (HPWS)-Performance relationship by presenting a review of existing literature and suggesting a comprehensive framework for schools in education industry.

Design/methodology/approach: A review of existing literature is presented followed by its critical assessment. A conceptual framework is then provided in order to determine the HPWS-Performance relationship in schools in education industry.

Findings: Existing HPWS-Performance literature has mostly focused on manufacturing sector ignoring the service sector especially the education industry, the authors suggest that this relationship be determined in this neglected sector while considering the "industry-specific" mediating and contingent factors which may have an effect on this relationship. The authors provide an integrated framework to measure the effect of HPWS on performance.

Research limitations/implications: The provided framework is yet to be tested empirically but can be used as a model for future research. 
Originality/value: The paper provides an overview of HPWS-Performance literature and provides a framework based on "industry-specific" factors for education industry for empirical testing.

Keywords: HPWS, Organizational Performance, Education industry, Organizational commitment, Human capital, Location, Student-Teacher ratio

Jel Codes: M10, I20, M12, M52, M53

\section{Introduction}

In the past two decades, Strategic Human Resource Management (SHRM) field has taken a pivotal role in Human Resource Management (HRM) literature by effectively illuminating the significant role of Human Resource (HR) in organizations. SHRM takes a holistic approach and postulates the notion that the groups or systems of HRM practices that are being observed in any organization make a significant impact to the organization's performance (Huselid, Jackson \& Schuler, 1997). These systems have been titled High Performance Work Systems (HPWS) (Huselid, 1995). Researchers have made same approaches towards HRM systems under different labels like high involvement or high commitment work systems etc. (Boxall, 2012; Wall \& Wood, 2005; Kim, Wright \& Su, 2010). However, the main concept behind all these researches point to the same conclusion that most important strengths of any organization are its individuals and the proper utilization of these individuals can lead to outstanding outcomes (Becker \& Huselid, 2006; Evans \& Davis, 2005). Based on this extensive concept HPWS can be used to denote such systems (Wei \& Lau, 2010).

In SHRM domain, numerous research studies have stated a statistically significant relationship between HPWS and firm performance (MacDuffie, 1995; Appelbaum, Bailey, Berg \& Kalleberg, 2000; Batt, 2002; Bae \& Lawler, 2000; Collings, Demirbag, Mellahi \& Tatoglu, 2010; Huselid, 1995; Collins \& Smith, 2006; Datta, Guthrie \& Wright, 2005; Guthrie, 2001; Sun, Aryee \& Law, 2007; Youndt, Snell, Dean \& Lepak, 1996; Delery \& Doty, 1996; Delaney \& Huselid, 1996; Way, 2002; Armstrong, Flood, Guthrie, Liu, Maccurtain \& Mkamwa, 2010; Kim \& Wright, 2011; Lee, Lee \& Kang, 2012). In 2006, meta analysis conducted by Combs, Lui, Hall and Ketchen analyzed 92 contemporary research studies on the HPWS-Performance relationship. Their analysis proved that when the standard deviation in the use of HPWS is raised by one, it results in a subsequent raise by $4.6 \%$ in return on resources. It also leads to a reduction in the turnover by $4.4 \%$ points. In the light of their analysis Combs et al. (2006, pp. 518) implied that "High performance work practices (HPWPs) impact on organizational performance is not only statistically significant, but managerially relevant". 
Over the years works enfolding the notion related to the HPWS-Performance link research stream have been a source of arguments. Various research works have initiated the procedure of laying down the foundation of SHRM on the basis of various theories, such as resource-based theory (Barney, 1991; Ulrich, 1991; Schuler \& MacMillan, 1984; Wright, Mcmahan \& Mcwilliams, 1994), behavioral perspective (Schuler \& Jackson, 1987; Jackson, Schuler \& Rivero, 1989), institutional perspective (Jackson \& Schuler, 1995; Jackson et al., 1989). Three distinct methods have also been utilized by the scholars in their quest to associate HR practices with organizational outcomes. The first of these methods is known as a universalistic or "best practices" approach. This approach suggests that preferred organizational achievements can be obtained through certain HR "best practices". The second in the aforementioned methods is the contingency approach. The contingency approach or "best fit" approach posits that progressive organizational outcomes will be achieved when organization's key external factors are associated with its HR practices. This approach asserts that the worth of HR practices is dependent on the attributes of an organization. The third is configurational approach which is derived from the contingency approach. The configurational approach asserts that for HR practices to make an influence on the organization's performance, it is imperative that these practices are arranged in a standardized configuration or in an array of practices and these practices should exhibit both the external (i.e. vertical) fit and the internal (horizontal) fit (Delery, 1998; Delery \& Doty, 1996; MacDuffie, 1995).

Though there has been considerable research conducted on the HPWS-Performance link, some crucial theoretical and methodological issues still remain unresolved (Wright, Mcmahan, Snell \& Gerhart, 2001a; Becker \& Gerhart, 1996; Delery, 1998; Cappelli \& Neumark, 2001; Guest, Michie, Conway \& Sheehan, 2003; Gerhart, 1999; Wall \& Wood, 2005; Gerhart, Wright, Mcmahan \& Snell, 2000; Wright, Gardner, Moynihan \& Allen, 2005; Boxall, 2012). Boxall (2012, pp. 170) admitted that HPWS "is a not a settled body of theory but an area of theoretical ferment". One of the important gap in this case is that despite the fact that the service sector has come out as a main supplier of the gross domestic product (GDP) in various developed and developing economies with seventy five percent of global workforce employed (Batt, 2002) and accounting for nearly sixty percent of economic activity in the whole world (Irons, 1994), majority of the literature sources basically outline the HPWS-Performance link research in manufacturing firms and neglect service sector (Bowen \& Schneider, 1988; Sun et al., 2007; Chand \& Katou, 2007; Chuang \& Liao, 2010). Much dissimilarity was observed between manufacturing and service sector in research study by Batt (2002) causing the author to conclude that findings in manufacturing sector can be generalized to a very limited extent to service sector. Contrary to the belief that the HPWPs are not as successful in the service sector, the study by Batt (2002) proved that the HPWPs enhance the organizational achievements. Datta et al. (2005) study also reported that HPWS-Performance relationship was higher in low 
capital intensive manufacturing industries as compared to high capital intensive ones. Many researchers (e.g., Arthur, 1994; Guest et al., 2003; Chand \& Katou, 2007; Datta et al., 2005; Ottenbacher, Gnoth \& Jones, 2006) have concluded that HR-Performance link must be tested in service industries which are more labor intensive and that such studies may result in stronger HPWS-Performance relationship. As a result of this constant argument in the past there is now growing interest among SHRM researchers to know how HPWS can be used by firms in service sector to achieve competitive advantage (Boxall, 2012).

In the service sector, education industry has been largely ignored by the SHRM scholars (Arthur, 1994; Scribner, Smylie \& Mosley, 2008). In a rare attempt in the past, the significance of this sector in HR research has been appreciated by few researchers (e.g., Bassi \& McMurrer, 2007, 2008; Young, 2008; Webb \& Norton, 2009) who laid stress on the utilization of HR practices to enhance the achievements of the education industry. However, there is lack of an integrated SHRM conceptual framework for education industry (Scribner et al., 2008). Bassi and McMurrer (2006) argued that education industry is like any other business industry and emphasized that the schools in the education industry face enormous competitive stress like any other business venture. Schools face new pressures from the administration to deliver by enhancing pupil achievement and grooming their pupils to survive and flourish in the world. These researchers argued that schools are also accountable to the public the same way as other businesses confront strain from stockholders to be responsible for their performances. Local citizens scrutinize the school performance assessing the revenue on the tax money they provide to the public education. According to Bassi and McMurrer (2006), with increasing attention of the residents towards accountability, there are more pressures on the education industry to show performance and to close the achievement gap. As a result school performance has been the focus of policy makers and researchers in education industry and they have always tried to seek the reasons behind the difference between good and poor performing school units (Rumberger \& Thomas, 2000). Due to the lack of any research in this area it is vital that the contribution of HPWS in this important labor intensive industry be critically assessed.

The purpose of this study is to contribute towards a better understanding of HPWSPerformance link by focusing on its possible application in schools in education industry. The paper provides an overview of the current HRM-Performance research along with the potential gaps identified by notable researchers and based on that propose a framework (as shown in Figure 1) for conducting future studies on the HRM- Performance link in schools in education industry by taking into account the specific mediating and contingency factors relative to this industry. 

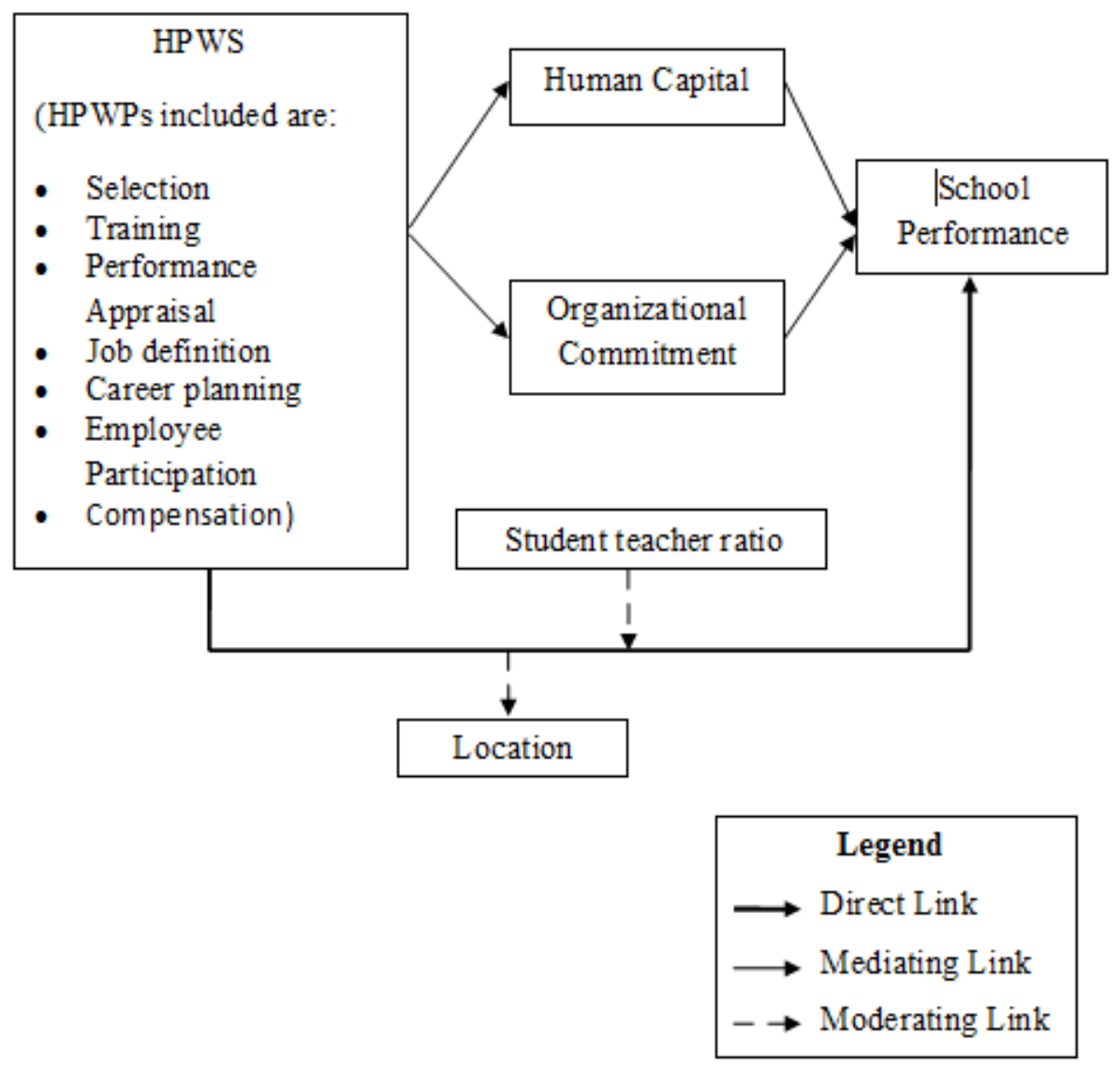

Figure 1. Conceptual Framework for Education Industry

Section 2 gives a brief overview of the relationship between HPWS and organizational performance followed by Section 3 which is focused on the framework for measuring HPWSPerformance relationship in schools in education sector. Resource Based View (RBV) is made the theoretical foundation for the framework presented in this study. Its major assumption is that firms' resources can be the source of their competitive advantage (Barney, 1991). HRM practices play a vital role in developing human capital of the organization which is considered to be an important source of competitive advantage (Huselid et al., 1997). This development of human capital further leads to increased firm performance. These HRM practices also trigger positive employee attitude which is another potential source of competitive advantage as argued by Fulmer, Gerhart and Scott (2003), thus leading to superior outcome. RBV contingency notion (Datta et al., 2005) additionally explains the potential impact of external factors on HPWS-Performance link. Section 4 comprises of the notable methodological controversies and their solutions as recommended by researchers in previous literature which should be considered while conducting the empirical testing of this framework. Section 5 provides the conclusion of the study. 


\section{HPWS-Performance Link}

HPWS include HR practices combinations which have a very positive effect on knowledge, skills, commitment and productivity of workforce in a firm (McMahan, Bell \& Virick, 1998; Datta et al., 2005). HPWS sees employees as the ones causing the organizations to attain competitive advantage and not as a typical source of expenditure (Becker \& Huselid, 1998). These systems stress on extensive engagement and empowerment of employees (Tamkin, 2004). In addition they contribute to problem solving and teamwork among employees (Youndt et al., 1996). There is growing consensus that conceptually HPWS should enhance employees Knowledge, Skill, Abilities (KSAs) (Huselid, 1995) thus increasing their motivation and commitment (Tamkin, 2004) resulting in greater individual and organizational performance (Delery \& Doty, 1996; Becker, Huselid, Pickus \& Spratt, 1997; Appelbaum et al., 2000; MacDuffie, 1995).

\subsection{Black Box between HRM and Performance}

Despite the previously-introduced theoretical approaches on the HPWS-Performance link, and relevant empirical studies; researchers have been inconclusive to specify the process involved in linking HPWS to performance (Gerhart, 1999; Becker \& Gerhart, 1996; Guest, 1997; Boudreau \& Ramstad, 1999; Dyer \& Reeves, 1995; Delery, 1998; Cappelli \& Neumark, 2001; Gerhart et al., 2000; Guest et al., 2003; Wall \& Wood, 2005; Wright et al., 2001a; Wright et al., 2005; Wright \& Gardner, 2003; Shore et al., 2004; Wright, Dunford \& Snell, 2001c). Researchers have termed this gap as "black box" between HPWS and performance (Dyer \& Shafer, 1999; Sun et al., 2007; Kim et al., 2010). Extant research, focusing on examination of some mediating factors that can be the content of this "black box" (e.g., Guest, 1997; Becker et al., 1997; Wright \& Nishii, 2006; Purcell, Hutchinson, Kinnie, Rayton \& Swart, 2003; Camps \& Luna-Arocas, 2012) did try to provide certain evidence for the existence of such a relationship. However need for more research to explore this mechanism has been strongly advocated (Guest, 1997; Bowen \& Ostroff, 2004; Delery \& Shaw, 2001; Paauwe, 2009; Savaneviciene \& Stankeviciute, 2010; Wei \& Lau, 2010) and need to make this issue a priority in SHRM research have been highlighted by notable researchers (Ferris, Hochwater, Buckley, Harrell-Cook \& Frink, 1999). 


\subsection{Contingent view of HRM Performance relationship}

Contemporary research suggests that the association between the HPWS and organizational outcomes is facilitated by extrinsic contextual factors (Kim et al., 2010) e.g., strategic orientation (Delery \& Doty, 1996), historical context (Appelbaum \& Batt, 1994) and industry characteristics (Datta et al., 2005). Besides the commonly argued contingent role of strategy (Huselid, 1995; Bird \& Beechler, 1995; Martell, Gupta \& Carroll, 1996; Delery \& Doty, 1996), country origin, firm size, organizational culture have also been examined for moderation in the HPWS-Performance link (Panayotopoulou, Bourantas \& Papalexandris, 2003; Bae, Chen, Wan, Lawler \& Walurnbwa, 2003; Chan, Shaffer \& Snape, 2004). However with the exception of the few research studies, the remaining literature related to this area does not highlight contingency variables effect like technology, size, age, location and unionization of firms which can have influence on HPWS-Performance relationship based on institutional perspective (Paauwe, 2004). Though some of these variables are occasionally incorporated into the model, the authors usually disregard their importance (Paauwe, 2004).

The previous review of literature demonstrates that the strategic emphasis placed upon human resource management has been shown to have beneficial consequences for organizations. However there are still concerns with respect to HPWS-Performance link and its growing body of research. These concerns stem from the theoretical and underdeveloped nature of this relationship as well as the equivocal findings demonstrated in the literature and may serve to continue to impair the growth of a theoretically strong body of research. In order to address these concerns a conceptual model for schools in education industry underlying this research is proposed. RBV has been used as theoretical framework for this model. RBV has been extensively used in SHRM. Based on RBV human capital and employee attitudes are termed to be potential source of competitive advantage (Huselid et al., 1997; Fulmer et al., 2003). These internal sources are positively driven by HRM practices thus leading to increased profits for organizations. This makes the basis for inclusion of potential mediating factors i.e., human capital and organizational commitment in HPWS-Performance link in schools in education industry. Additionally RBV contingency prospect has been utilized in this study to explain the moderating effects of "industry-specific" external factors on HPWS-Performance link in schools. According to this perspective, resources of the firm cannot be the means of competitive advantage until they make it possible for the firm to stand out in its specific competitive surroundings (Datta et al., 2005). As Barney (1995, pp. 52) stated, "Firm resources are not valuable in a vacuum, but rather are valuable only when they exploit opportunities and/or neutralize threats". This perspective has been used in the study to explain the effects of potential education industry related moderators on HPWS-Performance link. 


\section{HPWS-Performance Framework for Education Industry}

Based on previous literature, a comprehensive framework is laid in this section to evaluate HRM-Performance link in schools in education sector by taking into account all the important aspects in this relationship i.e., we recommend the inclusion of HPWS (independent variable), performance measures (dependent variable), set of mediators, contextual variables related to the education industry. The basis for this concept is to highlight the impact of these variables on performance through their size and level of significance. The framework is based on RBV theory which advocates that internal resources of an organization can be the means of competitive advantage. In order to explain the proposed framework, HPWPs included in HPWS, relative performance measures, possible mediators and contextual factors are discussed accordingly.

\subsection{HPWS Practices}

In this framework for schools in education sector, we propose that HPWS include HPWPs like selection, training, performance appraisal, job definition, career planning, employee participation and compensation. In an analysis conducted by Boselie, Dietz and Boon (2005), these HPWPs have also been among the top $10 \mathrm{HR}$ practices, which have been most consistently conceptualized as part of HPWS in previous 104 empirical research articles. Similarly these HPWPs were also listed among the most prominent HR practices based on analysis conducted on 25 most notable HPWS research studies by Wall and Wood (2005). In a meta analysis of previous 92 HPWS-Performance link research studies, Combs et al. (2006) also highlighted frequent use of these HPWPs. A brief review of these HPWPs is given below.

\subsubsection{Selection}

Recruitment and selection comprises of process of attracting and placing the right individual for the right job and these practices help in increasing productivity (Huselid, 1995). Selection practices have also been found to be positively affiliated with "labor productivity" (Koch \& McGrath, 1996), "perceived profit", "market share" (Verburg, 1998), "perceived market performance" (Delaney \& Huselid, 1996) and negatively associated with "employee turnover" (Huselid, 1995; Verburg, 1998). Attracting good teachers and their placement to the right place according to their qualification and expertise has also been termed vital for success of schools in education industry (Dove, 1982). 


\subsubsection{Training}

Training has been typically defined as attainment of knowledge and skills to perform different types of works in organization (Fitzgerald, 1992). The role of training in organizational effectiveness is two-fold. First, training programs enhance employee skills and abilities such that they become more productive workers, and the firm in turn becomes more productive (Goldstein, 1990). Second, training also serves a latent function of disseminating the worthiness of the employees in front of the organization (Moreland \& Levine, 2001). These employees, in turn, show a greater commitment to the organization. In context of education industry training of teachers has been found to be a very important factor in enhancing pupil achievement scores in a school unit (Dove, 1982).

\subsubsection{Performance Appraisal}

In HR literature performance appraisal has been described as "a process of systematically evaluating performance and providing feedback on which performance adjustments can be made" (Dransfield, 2000, pp. 71). Previously Delery and Doty (1996) demonstrated that results-oriented appraisals were positively related to firm performance. While no other studies have confirmed these specific results, work in the area of performance management has confirmed that the introduction of feedback systems (appraisals from multiple sources, or upward feedback from subordinates) is related to enhanced individual performance (e.g., Walker \& Smither, 1999; Johnson \& Ferstl, 1999; Smither, London, Vasilopoulos, Reilly, Millsap \& Salvemini, 1995) especially by those who were initially the lowest performers. In education industry performance appraisal of teachers is termed to be of considerable significance towards the school performance and has been termed as one of the motivating factors among school employees (Middlewood \& Cardno, 2001).

\subsubsection{Job Definition}

According to Delery and Doty (1996), job definition plays a very important role in effective working of employees. They state that a clearly elaborated job description generates duties of job which are clearly known to the employees and helps them in performing their tasks well in the organization. Also by ensuring employee involvement in deciding about the nature of work they will be performing, their motivation can be enhanced (Lado \& Wilson, 1994; Milgrom \& Roberts, 1992). Furthermore Miles and Darling-Hammond (1998) argued that effective job definition of employees is also one of the key characteristics of a high performing school in education sector. 


\subsubsection{Career Planning}

Career Planning in organizations helps the workforce not only to improve their abilities and skills vital for the organization but also motivate them to contribute towards their own development (Doyle, 1997). Firm performance is positively affected by career planning through enhanced motivation in employees (Osterman, 1987). In schools units of education sector, career planning practice has been termed extremely important for personal growth of teachers and for retaining them in schools (Margolis, 2008).

\subsubsection{Employee Participation}

Participation has been defined as "taking part" in HR literature (Vroom \& Jago, 1988). Participation affects the productivity of organization in various forms e.g., team participation has proved to affect quality and labor productivity of organization (Banker, Field, Schroeder \& Sinha, 1996). Other research studies have also proved the positive relationship between employee participation and satisfaction, performance and productivity of employee (Wagner, 1994; Pfeffer, 1994; Verma, 1995). It also enhances the performance of teachers in schools in education industry thus ultimately leading to improved school performance (Conley, 1991).

\subsubsection{Compensation}

Organizational performance has been associated with performance-based compensation in a variety of industries (Gerhart \& Milkovich, 1990; Banker, Lee, Potter \& Srinivasan, 1996; Milkovich \& Boudreau, 1998; Gómez-Mejía, Balkin \& Cardy, 1998). The pay level of employees' greatly influences the HPWS-Performance link (Becker \& Huselid, 1998). Increased pay level of the employees motivates them to more actively apply their skills and use their abilities to achieve organizational goals, which in turn increase organizational performance (Way, 2002). In education sector also, researchers have argued that high compensation for teachers can have a very positive effect on academic performance of students especially if it is linked with the performance of the teachers (Aslam, 2003). 


\subsection{School Performance Measures}

In most HPWS-Performance link research studies organizational performance factors have been related to typical manufacturing sector variables based on "financial outcomes" (e.g., worker's compensation, shrinkage, profitability, productivity) (Paauwe, 2009; Singh, Darwish, Costa \& Anderson, 2012). Becker and Gerhart (1996) and Paauwe (2009) argued that the dependent variable in SHRM studies will differ among levels and industries however they should be appropriate to the particular context. For the education industry, unit of analysis is school. Different performance measures can be utilized in the proposed framework. Literature related to school performance (e.g., Good \& Brophy, 1986; Cameron, 1978, 1981; Schneider, Glasheen \& Hadley, 1979; Reynolds, 1985; Keefe, Kelley \& Miller, 1985; MacKenzie, 1983; Ostroff, 1992) identifies number of school performance measures. The most notable are student behavior, academic achievement, teacher turnover, student satisfaction and administrative performance which can be used in the framework.

Based on the above mentioned discussion it is proposed that

- Proposition 1: HPWS will be positively related to School Performance

\subsection{Mediating Factors between HPWS and Performance}

Although previous literature has established a positive HPWS-Performance relationship (Delery \& Doty 1996; MacDuffie, 1995; Wright \& McMahan 1992; Huselid 1995; Arthur 1992, 1994), most of the studies have been unable to give any clue of the mechanism behind this link (Boselie et al., 2005). Many SHRM reviewers argue that HPWS-performance link is much more complex than the common perception (Wright \& Gardner, 2003). Though it has been established that the employees are vital asset of an organization, there is a scarcity of research that highlights the influence/ effect of multiple HR practices or systems on an individual (Wright \& Boswell, 2002). Kozlowski and Klein (2000) argued that performance is not exhibited by an organization; in fact it is the performance of the employees working there that enables the organization to acquire the required outcomes. Based on this argument, Lepak, Liao, Chung and Harden (2006) suggested that the HPWS actually augment cumulative employees' achievements thereby improving the organization's performance. Further explaining this process, Lepak et al. (2006) propositioned that firstly HPWS influence the employees' Knowledge, Skills and Abilities (KSAs) thus resulting in their increased performance and secondly HPWS motivates the employees' in a direct or indirect manner causing them to perform. Many notable researchers have endorsed this concept which is based on two factors i.e., collective human capital and collective attitudes, behaviors of the workforce of organization 
(Huselid, 1995; Wright \& Snell, 1991; Chang \& Chen, 2011). MacDuffie (1995, pp. 199) while explaining this concept posited that "skilled and knowledgeable workers who are not motivated are unlikely to contribute any discretionary effort. Motivated workers who lack skills or knowledge may contribute discretionary effort with little impact on performance" Hence, there are two methods by which HPWS can influence the organizational outcomes i.e., firstly, by increasing the employees commitment to the organization and secondly, by enhancing their KSAs. Consistent with this logic we propose two important mediators in this framework. The rationale of the two mediators is discussed below.

\subsubsection{Organizational Commitment}

Though there have been some studies which tried to explain mediating role of some factors in HPWS-Performance link, it's very seldom that the empirical research studies explore the mediation impacts of the attitudes of the workforce (Chow, 2003). As the attitudes comprise of both behavioral along with intuitive and intellectual components (Fishbein \& Ajzen, 1972), they are vital for determining the employee involvement and their demeanor in the workplace. Employee attitudes have also been found to be positively related to numerous organizational outcomes, as depicted by a meta-analysis (Harter, Schmidt \& Hayes, 2002). Organizational commitment is defined to be a key employee attitude which deals with their involvement in their organization (Porter, Steers, Mowday \& Boulin, 1974). Wright, Gardner and Moynihan (2003) posited that HR practices cause a "positive work environment" by enhancing employee commitment. They further argued that organizations having fully committed employees will be more productive.

\subsubsection{Human Capital}

Human capital is typically defined as "individual employee's knowledge, skills, and expertise" (Salamon, 1991; Youndt \& Snell, 2004). Human capital plays an important role in facilitation of HPWS in improving performance of firms (Huselid, 1995; Hsu, Lin, Lawler \& Hwawu, 2007). For example organizations practicing HPWS focus on rigorous selection and extensive learning opportunities, thereby enhancing KSAs of employees leading to improvement in their human capital (Way, 2002; Huselid, 1995). SHRM literature has strongly supported the effect of human capital on an organization's performance positing that it is the human capital of an organization which basically determines the impact of the employees' inherent contributions to the firm (Wright \& Snell, 1991; Pennings, Lee \& Van Witteloostuijin, 1998; Hatch \& Dyer, 2004; Coff, 1999; Barney, 1991; Carpenter, Sanders \& Gregersen, 2001). 
It is thus proposed that:

- Proposition 2a: Organizational commitment will mediate the relationship between HPWS and school performance

- Proposition 2b: Human capital will mediate the relationship between HPWS and school performance

\subsection{Contingent Factors in HPWS-Performance Link}

Contingency theory states that the relationship between the relevant independent variables (HPWS) and the dependent variable (organizational performance) will change according to influences such as industry/sector ownership, location, degree of unionization, company size, capital intensity and age and technology (Paauwe, 2004). In this context, resource based view (RBV) has been integrated with contingency prospect in literature. According to this perspective, resources of the firm cannot be the means of competitive advantage until they make it possible for the firm to stand out in its specific competitive surroundings. As Barney (1995, pp. 52) stated, "Firm resources are not valuable in a vacuum, but rather are valuable only when they exploit opportunities and/or neutralize threats". RBV supports the "fit" concept based on the fact that the worth provided by the firm resources can fluctuate from high and low values provisional to an organization's competitive environment. Nevertheless, all the existing research has not yet investigated the soundness of this concept (Datta et al., 2005). Based on the concept two important contingent factors which may influence HPWSPerformance link in schools in education sector are discussed below.

\subsubsection{Student/Teacher Ratio}

Student/teacher ratio also termed as class size (Alspaugh, 1994) is one of the important factors commonly considered while assessing the performance of schools in education industry as it influences quality of the school (Behrman, Khan, Ross \& Sabot, 1997). Student-teacher ratio depicts the workload on teacher and the extent to which teacher is available to students (Smith, 2001). Decrease in student-teacher ratio increases teacher availability along with higher instructional flexibility (Ellis, 1984) and more learning for students (Lee, Smith \& Croninger, 1997; Lee, Bryk \& Smith, 1993; Bryk, Lee \& Holland, 1993; Lee \& Smith, 1993, $1995,1996)$ thus contributing positively towards their achievement scores (Suryadarma, Suryahadi, Sumarto \& Rogers, 2006). Many previous research studies have endorsed the negative relationship between student teacher ratio and student achievement scores 
(Akerhielm, 1995; Sander, 1999; Boozer \& Rouse, 2001; Mosteller, 1995; Krueger \& Whitmore, 2001; Alderman Behrman, Khan, Ross \& Sabot, 1995; Darling-Hammond, 2000; Lee \& Smith, 1997; Krueger, 1999; Case \& Deaton, 1999; Angrist \& Lavy, 1999; Behrman et al., 1997). From the above discussion it is evident that there is strong need to assess the contingent role of student/teacher ratio in HPWS and organizational performance relationship.

\subsubsection{Location}

Location of the industry can also be one of the potential contingency factors in HPWSPerformance link (Paauwe, 2009). Location plays an important role in determining school performance (Rumberger \& Thomas, 2000). The difference in urban and rural schools performance has been observed in both developing and developed countries (Dove, 1982; Fan \& Chen, 1999). In many previous research studies related to education industry urban school units have been found to perform better than rural school units (e.g. Lindberg, Nelson \& Nelson, 1985; Greenberg \& Teixeira, 1995; Edington \& Koehler, 1987; Coe, Howley \& Hughes, 1989a, b; Young, 1998; Saeed, Gondal \& Bushra, 2005; Haque, Kalhoro \& Saeed, 2000; Alderman et al., 1995; Stockhausen \& Soyibo, 2004). Factors that has been observed to be responsible for the dissimilar performance of urban-rural school units include teaching quality, teachers' training (Young, 1998; Cross \& Schwertzbaun, 1969), teaching facilities (Soyibo \& Johnson, 1998), parental and community support (Young, 1998); socio economic status (Von Secker, 2004; Coladarci \& Cobb, 1996), students perception of school safety (Williams, 1996; McCombs \& Bansberg, 1997; Caplan, 1995), class and school size (Howely \& Gunn, 2003), students self-concept, teaching strategies, teachers qualification, school condition and availability of academic resources (Herzog \& Pittman, 1995), school conditions, facilities and population education (Coleman, 1966). The important role of location in education industry evident from above arguments drives the need to consider location as a contingent factor while assessing HPWS-Performance link in education industry.

It is thus proposed that:

- Proposition 3a: Student/teacher ratio will moderate the relationship between HPWS and school performance

- Proposition 3b: Location will moderate the relationship between HPWS and school performance 


\section{Methodological issues in HPWS-Performance Framework}

An important concern raised by most SHRM researchers is that majority of the literature on HPWS and performance is cross-sectional (Singh et al., 2012), thus rendering it hard to be certain about the causality of HPWS-Performance link (Guest, 2011). This issue becomes more critical when review of most of limited longitudinal research work done (see, e.g. Wright et al., 2005; Guest et al., 2003) depicts that HPWS cease to stimulate performance, when the past performance is controlled. Wright et al. (2005) and Paauwe and Boselie (2005) have given alternative explanations of these abnormal causality results e.g., according to them one of the reasons can be that high performing organizations at one point in time maybe investing their extra resources on HR practices resulting in improved performance afterwards. In order to determine the reverse causality Wall and Wood (2005) suggested an alternative of longitudinal design study called "quasi-longitudinal" study which is an enhancement of typical cross sectional study pursued in HPWS-Performance research. In this kind of study relationship of HPWS and firm performance can be examined at any point in time while "controlling for past performance" thus determining the reverse causality as well (Wall \& Wood, 2005) which longitudinal design is unable to detect (Wright et al., 2005). Thus conflicting results of the very limited and rare research work in "reverse causality" context further indicate the necessity of inclusion of this research design in future empirical research work to comprehend the convoluted notion of causality (Wright et al., 2005; Becker \& Huselid, 2006; Guest, 2011; Paauwe, 2009).

An important measurement issue in previous HPWS-Performance link studies concerns the source of data for HPWPs (Arthur \& Boyles, 2007; Wall \& Wood, 2005; Guest, 2011). Given that most prior studies use a set of HPWPs as the proxy, the data is collected from HR managers/executives. A single respondent is usually adopted. Validity of the construct is then threatened, due to containment of large measurement error. Wright, Gardner, Moynihan, Park, Gerhart and Delery (2001b) provided evidence for emergence of such measurement error by testing on three organizations from different industries at the corporate level, business and job level, respectively. Further suggestions were provided by Gerhart et al. (2000) that the generalizability theory can be used for a better estimates of reliability in HPWS-performance research, suggesting that for dealing with this problem in measurement, multiple raters for HPWPs should be employed in future studies. Wright and Boswell (2002) stressed that it is critical to measure "actual HR practices" being implemented by the organizations instead of the "HR policies" which are the intended practices that should be implemented by the organization. In order to do that Wright and Boswell (2002) pointed out that it is important that employees should be the source of data for HR practices instead of HR managers/executives. Though many SHRM researchers have stressed for multiple raters for measuring HPWPs (e.g, Edgar \& 
Geare, 2009; Wright, Gardner \& Moynihan, 2003; Wright \& Gardner, 2003; Arthur \& Boyles, 2007; Guest, 2011; Wall \& Wood, 2005), very few studies have followed this recommendation (Batt \& Banerjee, 2012).

\section{Conclusion}

HRM-Performance relationship has been the central focus of SHRM research for more than two decades. The contribution of the HRM systems towards organizational performance in various corporate sectors has been recognized by notable researchers and industry gurus. However most of this research has been based on manufacturing sector. Keeping in view the importance of service industry especially schools in education industry in present world economy, it is vital that this relationship be determined in this labor intensive industry by taking into consideration the industry-specific factors as argued by notable SHRM researchers. The conceptual model has been provided in this study to facilitate the determination of HRM-Performance relationship in schools in education sector. The model includes the HRM System, relative mediators and education industry specific contingent factors and performance factors. Methodological issues in this context surrounding the HRM-Performance literature have also been discussed along with the recommendations of the SHRM researchers to counter these issues. The authors believe that this conceptual model will be an important contribution towards HPWSPerformance research and intend to test this model empirically in near future. 


\section{References}

AKERHIELM, K. (1995). Does class size matter?. Economics of Education Review, 14(3): 229-241. http://dx.doi.org/10.1016/0272-7757(95)00004-4

ALDERMAN, H.; BEHRMAN, J.R.; KHAN, S.; ROSS, D.R.; SABOT, R. (1995). Public schooling expenditure in rural Pakistan: Efficiently targeting girls and a lagging region. In D. De Walle \& K. Nead (Eds.), Public spending and the poor, theory and evidence. Baltimore, Maryland: The Johns Hopkins University Press.

ALSPAUGH, J.W. (1994). The relationship between student size, student teacher ratio and school efficiency. Education, 114(4): 593-601.

ANGRIST, J.D.; LAVY, V. (1999). Using maimonides' rule to estimate the effect of class-size on scholastic achievement. The Quarterly Journal of Economics, 114(2): 533-575. http://dx.doi.org/10.1162/003355399556061

APPELBAUM, E.; BATT, R. (1994). The new American workplace: Transforming work systems in the United States. Ithaca, NY: ILR Press.

APPELBAUM, E.; BAILEY, T.; BERG, P.; KALLEBERG, A. (2000). Manufacturing advantage: Why high-performance work systems pay off. Ithaca, NY: ILR Press.

ARMSTRONG, C.; FLOOD, P.C.; GUTHRIE, J.P.; LIU, W.; MACCURTAIN, S.; MKAMWA, T. (2010). The impact of diversity and equality management on firm performance: Beyond high performance work systems. Human Resource Management, 49(6): 977-998. http://dx.doi.org/10.1002/hrm.20391

ARTHUR, J.B. (1992). The link between business strategy and industrial relations systems in american steel mills. Industrial and Labor Relations Review, 45(3): 488-506. http://dx.doi.org/10.2307/2524274

ARTHUR, J.B. (1994). Effects of human resource systems on manufacturing performance and turnover. Academy of Management Journal, 37(3): 670-687. http://dx.doi.org/10.2307/256705

ARTHUR, J.B.; BOYLES, T. (2007). Validating the human resource system structure: A levelsbased strategic HRM approach. Human Resource Management Review, 17(1): 77-92. http://dx.doi.org/10.1016/j.hrmr.2007.02.001

ASLAM, M. (2003). The determinants of student achievement in government and private schools in Pakistan. The Pakistan Development Review, 42(4): 841-876.

BAE, J.; LAWLER, J.J. (2000). Organizational and HRM strategies in Korea: Impact on firm performance in an emerging economy. Academy of Management Journal, 43(3): 502-517. http://dx.doi.org/10.2307/1556407 
BAE, J.; CHEN, S.; WAN, T.W.; LAWLER, J.J.; WALURNBWA, F.O. (2003). Human resource strategy and firm performance in Pacific Rim countries. International Journal of Human Resource Management, 14(8): 1308-1332. http://dx.doi.org/10.1080/0958519032000145774

BANKER, R.D.; FIELD, J.M.; SCHROEDER, R.G.; SINHA, K.K. (1996). Impact of work teams on manufacturing performance: A longitudinal field study. Academy of Management Journal, 39(4): 867-890. http://dx.doi.org/10.2307/256715

BANKER, R.D.; LEE, S.Y.; POTTER, G.; SRINIVASAN, D. (1996). Contextual analysis of performance impacts of outcome-based incentive compensation. Academy of Management Journal, 39(4): 920-948. http://dx.doi.org/10.2307/256717

BARNEY, J.B. (1991). Firm resources and sustained competitive advantage. Journal of Management, 17(1): 99-120. http://dx.doi.org/10.1177/014920639101700108

BARNEY, J.B. (1995). Looking inside for competitive advantage. Academy of Management Executive, 9(4): 49-61.

BASSI, L.J.; MCMURRER, D.P. (2006). The business of learning: South Carolina school district offers an education in superior human capital management. Brooklyn, NY: McBassi and Company, Inc.

BASSI, L.J.; MCMURRER, D.P. (2007). Maximizing your return on people. Harvard Business Review, 85(3): 115-123.

BASSI, L.J.; MCMURRER, D.P. (2008). Toward a human capital measurement methodology. Advances in Developing Human Resources, 10(6): 863-881. http://dx.doi.org/10.1177/1523422308325611

BATT, R. (2002). Managing customer services: Human resource practices, quit rates, and sales growth. Academy of Management Journal, 45(3): 587-597. http://dx.doi.org/10.2307/3069383

BATT, R.; BANERJEE, M. (2012). The scope and trajectory of strategic HR research: Evidence from American and British journals. The International Journal of Human Resource Management, 23(9): 1739-1762. http://dx.doi.org/10.1080/09585192.2011.610933

BECKER, B.; GERHART, B. (1996). The impact of human resource management on organizational performance: Progress and prospects. Academy of Management Journal, 39(4): 779-801. http://dx.doi.org/10.2307/256712

BECKER, B.E.; HUSELID, M.A.; PICKUS, P.S.; SPRATT, M.F. (1997). HR as a source of shareholder value: Research and recommendations. Human Resource Management, 36(1): 39-47. http://dx.doi.org/10.1002/(SICI)1099-050X(199721)36:1<39::AID-HRM8>3.0.CO;2-X 
BECKER, B.E.; HUSELID, M.A. (1998). High performance work systems and firm performance: A synthesis of research and managerial implications. In Ferris, G.E. (Ed.), Research in personnel and human resources management (16: 53-102). Greenwich, CT: JAI Press Inc.

BECKER, B.E.; HUSELID, M.A. (2006). Strategic human resources management: Where do we go from here?. Journal of Management, 32(6): 898-925.

http://dx.doi.org/10.1177/0149206306293668

BEHRMAN, J.R.; KHAN, S.; ROSS, D.; SABOT, R. (1997). School quality and cognitive achievement production: A case study for rural Pakistan. Economics of Education Review, 16(2): 127-142. http://dx.doi.org/10.1016/S0272-7757(96)00045-3

BIRD, A.; BEECHLER, S. (1995). Links between business strategy and human resource management strategy in US-based Japanese subsidiaries: An empirical investigation. Journal of International Business Studies, 26(1): 23-46.

http://dx.doi.org/10.1057/palgrave.jibs.8490164

BOOZER, M.; ROUSE, C. (2001). Intraschool variation in class size: Patterns and implications. Journal of Urban Economics, 50(1): 163-189. http://dx.doi.org/10.1006/juec.2001.2216

BOSELIE, P.; DIETZ, G.; BOON, C. (2005). Commonalties and contradictions in HRM and performance research. Human Resource Management Journal, 15(3): 67-94.

http://dx.doi.org/10.1111/j.1748-8583.2005.tb00154.x

BOUDREAU, J.; RAMSTAD, P. (1999). Human resource metrics: Can measures be strategic. In P. Wright, L. Dyer, J. Boudreau \& G. Milkovich (Eds.), Strategic human resources management in the twenty-first century (4: 75-98). Stamford, CT: JAI Press Inc.

BOWEN, D.E.; SCHNEIDER, B. (1988). Services marketing and management: Implications for organizational behavior. In B.M. Staw \& L.L. Cummings (Eds.), Research in organizational behavior. Greenwich, CT: JAI Press, Inc.

BOWEN, D.E.; OSTROFF, C. (2004). Understanding HRM firm performance linkages: The role of the "strength" of the HRM system. Academy of Management Review, 29(2): 203-221.

BOXALL, P. (2012). High-performance work systems: What, why, how and for whom?. Asia Pacific Journal of Human Resources, 50(2): 169-186. http://dx.doi.org/10.1111/j.17447941.2011.00012.x

BRYK, A.S.; LEE, V.E.; HOLLAND, P.B. (1993). Catholic schools and the common good. Cambridge, MA: Harvard University Press.

CAMERON, K.S. (1978). Measuring organizational effectiveness in institutions of higher education. Administrative Science Quarterly, 23(4): 604-632. http://dx.doi.org/10.2307/2392582 
CAMERON, K.S. (1981). Domains of organizational effectiveness in colleges and universities. Academy of Management Journal, 24(1): 25-47. http://dx.doi.org/10.2307/255822

CAMPS, J.; LUNA-AROCAS, R. (2012). A matter of learning: How human resources affect organizational performance. British Journal of Management, 23(1): 1-21.

CAPLAN, J.G. (1995). Parent involvement 101: A guide for rural educators. Rural School Development Outreach Project.

CAPPELLI, P.; NEUMARK, D. (2001). Do "High performance" Work practices improve establishment level outcomes?. Industrial and Labor Relations Review, 54(4): 737-775. http://dx.doi.org/10.2307/2696111

CARPENTER, M.A.; SANDERS, W.G.; GREGERSEN, H.B. (2001). Building human capital with organizational context: The impact of international assignment on multinational firm performance and CEO pay. Academy of Management Journal, 44(3): 493-511. http://dx.doi.org/10.2307/3069366

CASE, A.; DEATON, A. (1999). School inputs and educational outcomes in South Africa. The Quarterly Journal of Economics, 114(3): 1047-1084. http://dx.doi.org/10.1162/003355399556124

CHAN, L.L.M.; SHAFFER, M.A.; SNAPE, E. (2004). In search of sustained competitive advantage: The impact of organizational culture, competitive strategy and human resource management practices on firm performance. International Journal of Human Resource Management, 15(1): 17-35. http://dx.doi.org/10.1080/0958519032000157320

CHAND, M.; KATOU, A.A. (2007). The impact of human resource management on organisational performance in the Indian hotel industry. Employee Relations, 29(6): 576-594. http://dx.doi.org/10.1108/01425450710826096

CHANG, P.; CHEN, S. (2011). Crossing the level of employee's performance: HPWS, affective commitment, human capital, and employee job performance in professional service organizations. The International Journal of Human Resource Management, 22(4): 883-901. http://dx.doi.org/10.1080/09585192.2011.555130

CHOW, R.H. (2003). High-performance work systems in Asian companies. Thunderbird International Business Review, 47(5): 575-599. http://dx.doi.org/10.1002/tie.20068

CHUANG, C.; LIAO, H. (2010). Strategic human resource management in service context: Taking care of business by taking care of employees and customers. Personnel Psychology, 63(1): 153-196. http://dx.doi.org/10.1111/j.1744-6570.2009.01165.x

COE, P.; HOWLEY, C.B.; HUGHES, M. (1989a). The condition of rural education in Kentucky: A profile. Charleston, WV: Appalachia Educational Laboratory. 
COE, P.; HOWLEY, C.B.; HUGHES, M. (1989b). The condition of rural education in Virginia: A profile. Charleston, WV: Appalachia Educational Laboratory.

COFF, R.W. (1999). How control in human-asset-intensive firms differs from physical-assetintensive firms. Journal of Managerial Issues, 11(4): 389-406.

COLADARCI, T.; COBB, C.D. (1996). Extracurricular participation, school size, and achievement and self-esteem among high school students: A national look. Journal of Research in Rural Education, 12(2): 92-103.

COLEMAN, J.S. (1966). Equality of educational opportunity. Washington: U.S. Government Printing Office.

COLLINGS, D.G.; DEMIRBAG, M.; MELLAHI, K.; TATOGLU, E. (2010). Strategic orientation, human resource management practices and organizational outcomes: Evidence from Turkey. The International Journal of Human Resource Management, 21(14): 2589-2613. http://dx.doi.org/10.1080/09585192.2010.523577

COLLINS, C.J.; SMITH, K.G. (2006). Knowledge exchange and combination: The role of human resource practices in the performance of high-technology firms. Academy of Management Journal, 49(3): 544-560. http://dx.doi.org/10.5465/AMJ.2006.21794671

COMBS, J.; LUI, Y.; HALL, A.; KETCHEN, D. (2006). How much do high-performance work practices matter? A meta-analysis of their effects on organizational performance. Personnel Psychology, 59(3): 501-528. http://dx.doi.org/10.1111/j.1744-6570.2006.00045.x

CONLEY, S. (1991). Review of research on teacher participation in school decision making. In G. Grant (Ed.), Review of research in education (pp. 225-266). Washington, DC: American Educational Research Association.

CROSS, M.; SCHWERTZBAUN, A.M. (1969). Social mobility and secondary relation in Trinidad and Tobago. In P.M.E. Figueroa \& G. Persaud (Eds.), Sociology of education. Oxford: Oxford University Press.

DARLING-HAMMOND, L. (2000). Teacher quality and student achievement: A review of state policy evidence. Educational Policy Analysis Archives, 8(1): 123-140.

DATTA, D. K.; GUTHRIE, J.P.; WRIGHT, P.M. (2005). Human resource management and labor productivity: Does industry matter?. Academy of Management Journal, 48(1): 135-145. http://dx.doi.org/10.5465/AMJ.2005.15993158

DELANEY, J.T.; HUSELID, M.A. (1996). The impact of human resource management practices on perceptions of organizational performance. Academy of Management Journal, 39(4): 949-969. http://dx.doi.org/10.2307/256718 
DELERY, J.E.; DOTY, D.H. (1996). Modes of theorizing in strategic human resource management: Tests of universalistic, contingency, and configurational performance predictions. Academy of Management Journal, 39(4): 802-835. http://dx.doi.org/10.2307/256713

DELERY, J.E. (1998). Issues of fit in strategic human resource management: Implications for research. Human Resource Management Review, 8(3): 289-309.

http://dx.doi.org/10.1016/S1053-4822(98)90006-7

DELERY, J.E.; SHAW, D. (2001). The strategic management of people in work organizations: Review, synthesis and extension. In G.R. Ferris (Ed.), Research in personnel and human resources management (20: 165-197). Stamford, CT: JAI Press.

DOVE, L.A. (1982). The deployment and training of teachers for remote rural schools in lessdeveloped countries. International Review of Education, 28(1): 3-27. http://dx.doi.org/10.1007/BF00597756

DOYLE, M. (1997). Management development. In I. Beardwell \& L. Holden (Eds.), Human resource management: A contemporary perspective (pp. 212-235). London: Pitman.

DRANSFIELD, R. (2000). Human resource management. Oxford: Heinemann.

DYER, L.; REEVES, T. (1995). Human resource strategies and firm performance: What do we know and where do we need to go?. International Journal of Human Resource Management, 6(3): 656-670. http://dx.doi.org/10.1080/09585199500000041

DYER, L.; SHAFER, R.A. (1999). From human resource strategy to organizational effectiveness: Lessons from research on organizational agility. In M.A. Wright, L.D. Dyer, J.W. Boudreau \& G.T. Milkovich (Eds.), Research in personnel and human resource management (4: 145-174). Greenwich, CT: JAI Press.

EDGAR, F.; GEARE, A. (2009). Inside the "Black box" and "HRM". International Journal of Manpower, 30(3): 220-236. http://dx.doi.org/10.1108/01437720910956736

EDINGTON, E.D.; KOEHLER, L. (1987). Rural student achievement: Elements for consideration. Las Cruces, NM: New Mexico State University.

ELLIS, T.I. (1984). Class size. ERIC clearinghouse on educational management. Washington, DC: National Institute of Education (Ed.).

EVANS, W.R.; DAVIS, W.D. (2005). High-performance work systems and organizational performance: The mediating role of internal social structure. Journal of Management, 31(5): 758-775. http://dx.doi.org/10.1177/0149206305279370

FAN, X.; CHEN, M.J. (1999). Academic achievement of rural school students: A multi-year comparison with their peers in suburban and urban schools. Journal of Research in Rural Education, 15(1): 31-46. 
FERRIS, G.; HOCHWATER, W.A.; BUCKLEY, M.R.; HARRELL-COOK, G.; FRINK, D.D. (1999). Human resource management: Some new directions. Journal of Management, 25(3): 385-415. http://dx.doi.org/10.1177/014920639902500306

FISHBEIN, M.; AJZEN, I. (1972). Attitudes and opinions. Annual Review of Psychology, 23(1): 487-544. http://dx.doi.org/10.1146/annurev.ps.23.020172.002415

FITZGERALD, W. (1992). Training versus development. Training and Development, 46(5): 81-84.

FULMER, I.S.; GERHART, B.; SCOTT, K.S. (2003). Are the 100 best better? An empirical investigation of the relationship between being a "great place to work" and firm performance. Personnel Psychology, 56(4): 965-993.

http://dx.doi.org/10.1111/j.1744-6570.2003.tb00246.x

GERHART, B.; MILKOVICH, G. (1990). Organizational differences in managerial compensation and financial performance. Academy of Management Journal, 33(4): 663-691. http://dx.doi.org/10.2307/256286

GERHART, B. (1999). Human resource management and firm performance: Measurement issues and their effect on causal and policy inferences. In P.M. Wright, L. Dyer \& J.W. Boudreau (Eds.), Research in personnel and human resources management, 17: 31-51.

GERHART, B.; WRIGHT, P.M.; MCMAHAN, G.C.; SNELL, S.A. (2000). Measurement error in research on human resources and firm performance: How much error is there and how does it influence effect size estimates?. Personnel Psychology, 53(4): 803-834.

http://dx.doi.org/10.1111/j.1744-6570.2000.tb02418.x

GOLDSTEIN, I.L. (1990). Training in work organizations. In M.D. Dunnutte \& L.M. Hough (Eds.), Handbook of industrial and organizational psychology (pp. 507-619). Palo Alto, CA: Consulting Psychologists Press.

GÓMEZ-MEJÍA, L.; BALKIN, D.B.; CARDY, R.L. (1998). Managing human resources (2nd ed.). Englewood Cliffs, NJ: Prentice-Hall.

GOOD, T.L.; BROPHY, J.E. (1986). School effects. In M.C. Wittrock (Ed.), Handbook of research on teaching (pp. 570-602). New York: Macmillan.

GREENBERG, E.J.; TEIXEIRA, R.A. (1995). Nonmetro student achievement on par with metro. Rural Development Perspectives, 10: 17-23.

GUEST, D.E. (1997). Human resource management and performance: A review and research agenda. International Journal of Human Resource Management, 8(3): 263-276.

http://dx.doi.org/10.1080/095851997341630 
GUEST, D.E.; MICHIE, J.; CONWAY, N.; SHEEHAN, M. (2003). A study of human resource management and corporate performance in the UK. British Journal of Industrial Relations, 41(2): 291-314. http://dx.doi.org/10.1111/1467-8543.00273

GUEST, D.E. (2011). Human resource management and performance: Still searching for some answers. Human Resource Management Journal, 21(1): 3-13. http://dx.doi.org/10.1111/j.17488583.2010.00164.x

GUTHRIE, J.P. (2001). High-involvement work practices, turnover, and productivity: Evidence from New Zealand. Academy of Management Journal, 44(1): 180-190.

http://dx.doi.org/10.2307/3069345

HAQUE, M.; KALHORO, S.; SAEED, S. (2000). Baseline survey of learning. Jamshoro: Bureau of Curriculum Development and Extension Wing.

HARTER, J.K.; SCHMIDT, F.L.; HAYES, T.L. (2002). Business-unit-level relationship between employee satisfaction, employee engagement, and business outcomes: A meta-analysis. Journal of Applied Psychology, 87(2): 268-279. http://dx.doi.org/10.1037/0021-9010.87.2.268

HATCH, N.W.; DYER, J.H. (2004). Human capital and learning as a source of sustainable competitive advantage. Strategic Management Journal, 25(12): 1155-1178. http://dx.doi.org/10.1002/smj.421

HERZOG, M.J.R.; PITTMAN, R.B. (1995). Home, family, and community: Ingredients in the rural education equation. Phi Delta Kappan, 77(2): 113-118.

HOWELY, C.B.; GUNN, E. (2003). Research about mathematics achievement in the rural circumstance. Journal of Research in Rural Education, 18(2): 79-100.

HSU, I.C.; LIN, C.Y.Y.; LAWLER, J.J.; HWAWU, S. (2007). Toward a model of organizational human capital development: Preliminary evidence from Taiwan. Asia Pacific Business Review, 13(2): 251-275. http://dx.doi.org/10.1080/13602380701233547

HUSELID, M.A. (1995). The impact of human resource management practices on turnover, productivity, and corporate financial performance. Academy of Management Journal, 38(3): 635-672. http://dx.doi.org/10.2307/256741

HUSELID, M.A.; JACKSON, S.E.; SCHULER, R.S. (1997). Technical and strategic human resource management effectiveness as determinants of firm performance. Academy of Management Journal, 40(1): 171-188. http://dx.doi.org/10.2307/257025

IRONS, K. (1994). Managing service companies: Strategies for success. Wokingham: Addison Wesley. 
JACKSON, S.E.; SCHULER, R.S.; RIVERO, J.C. (1989). Organizational characteristics as predictors of personnel practices. Personnel Psychology, 42(4): 727-786. http://dx.doi.org/10.1111/j.1744-6570.1989.tb00674.x

JACKSON, S.E.; SCHULER, R.S. (1995). Understanding human resource management in the context of organizations and their environments. Annual Review of Psychology, 46(1): 237-264. http://dx.doi.org/10.1146/annurev.ps.46.020195.001321

JOHNSON, J.W.; FERSTL, K.L. (1999). The effects of interrater and self-other agreement on performance improvement following upward feedback. Personnel Psychology, 52(2): 271-303. http://dx.doi.org/10.1111/j.1744-6570.1999.tb00162.x

KEEFE, J.W.; KELLEY, E.A.; MILLER, S.K. (1985). School climate: Clear definitions and a model for a larger setting. NASSP Bulletin, 69(484): 70-77. http://dx.doi.org/10.1177/019263658506948416

KIM, S.; WRIGHT, P.; SU, Z. (2010). Human resource management and firm performance in china: A critical review. Asia Pacific Journal of Human Resources, 48(1): 58-85. http://dx.doi.org/10.1177/1038411109356496

KIM, S.; WRIGHT, P.M. (2011). Putting strategic human resource management in context: A contextualized model of high commitment work systems and its implications in China. Management and Organization Review, 7(1): 153-174.

http://dx.doi.org/10.1111/j.1740-8784.2010.00185.x

KOCH, M. J.; MCGRATH, R.G. (1996). Improving labor productivity: Human resource management policies do matter. Strategic Management Journal, 17(5): 335-354. http://dx.doi.org/10.1002/(SICI)1097-0266(199605)17:5<335: :AID-SMJ814>3.0.CO;2-R

KOZLOWSKI, S.W.; KLEIN, K.J. (2000). A multilevel approach to theory and research in organizations: Contextual, temporal and emergent processes. In K.J. Klein \& S.W. Kozlowski (Eds.), Multilevel theory. Research and methods in organizations (pp. 3-90). San Francisco: Jossey-Bass.

KRUEGER, A.B. (1999). Experimental estimates of education production functions. The Quarterly Journal of Economics, 114(2): 497-532. http://dx.doi.org/10.1162/003355399556052

KRUEGER, A.B.; WHITMORE, D.M. (2001). The effect of attending a small class in the early grades on college-test taking and middle school test results: Evidence from project star. Economic Journal, 111(468): 1-28. http://dx.doi.org/10.1111/1468-0297.00586

LADO, A.A.; WILSON, M.C. (1994). Human resource systems and sustained competitive advantage: A competency-based perspective. Academy of Management Review, 19(4): 699-727. 
LEE, S.M.; LEE, D.; KANG, C. (2012). The impact of high-performance work systems in the health-care industry: Employee reactions, service quality, customer satisfaction, and customer loyalty. The Service Industries Journal, 32(1): 17-36.

http://dx.doi.org/10.1080/02642069.2010.545397

LEE, V.E.; SMITH, J.B. (1993). Effects of school restructuring on the achievement and engagement of middle-grade students. Sociology of Education, 66(3): 164-187.

http://dx.doi.org/10.2307/2112735

LEE, V.E.; BRYK, A.S.; SMITH, J.B. (1993). The organization of effective high schools. In L. Darling-Hammond (Ed.), Review of research in education (19: 171-267). Washington D.C: American Educational Research Association.

LEE, V.E.; SMITH, J.B. (1995). The effects of high school restructuring and size on gains in achievement and engagement for early secondary school students. Sociology of Education, 68(4): 271-290. http://dx.doi.org/10.2307/2112741

LEE, V.E.; SMITH, J.B. (1996). Collective responsibility for learning and its effects on gains in achievement for early secondary school students. American Journal of Education, 104(2): 103-147. http://dx.doi.org/10.1086/444122

LEE, V.E.; SMITH, J.B. (1997). High school size: Which works best and for whom?. Educational Evaluation and Policy analysis, 19(3): 205-227. http://dx.doi.org/10.3102/01623737019003205

LEE, V.E.; SMITH, J.B.; CRONINGER, R.G. (1997). How high school organization influences the equitable distribution of learning in mathematics and science. Sociology of Education, 70(2): 129-152. http://dx.doi.org/10.2307/2673160

LEPAK, D.P.; LIAO, H.; CHUNG, Y.; HARDEN, E.E. (2006). A conceptual review of human resource management systems in strategic human resource management research. Research in personnel and human resources management (25: 217-271). Greenwich, CT: JAI Press. http://dx.doi.org/10.1016/S0742-7301(06)25006-0

LINDBERG, D.; NELSON, D.; NELSON, K. (1985). Small high schools in Utah: A status report. Charleston, WV: Appalachia Educational Laboratory.

MACDUFFIE, J.P. (1995). Human resource bundles and manufacturing performance: Organizational logic and flexible production systems in the world auto industry. Industrial and Labor Relations Review, 48(2): 197-221. http://dx.doi.org/10.2307/2524483

MACKENZIE, D.E. (1983). Research for school improvement: An appraisal of some recent trends. Educational Researcher, 12(4): 5-17. http://dx.doi.org/10.3102/0013189x012004005

MARGOLIS, J. (2008). What will keep today's teachers teaching? Looking for a hook as a new career cycle emerges. Teachers College Record, 110(1): 160-194. 
MARTELL, K.; GUPTA, A.; CARROLL, S.J. (1996). Human resource management practices, business strategies, and firm performance: A test of strategy implementation theory. Irish Business and Administrative Research, 17(1): 18-35.

MCCOMBS, B.L.; BANSBERG, B. (1997). Meeting student diversity needs in poor, rural schools: Ideal practices and political realities. In M.C. Wang \& K.K. Wong (Eds.), Implementing school reform: Practice and policy imperatives (pp. 161-192). Philadelphia, PA: Temple University Center for Research in Human Development and Education.

MCMAHAN, G.; BELL, M.; VIRICK, M. (1998). Strategic human resource management: Employee involvement, diversity, and international issues. Human Resource Management Review, 8(3): 193-214. http://dx.doi.org/10.1016/S1053-4822(98)90002-X

MIDDLEWOOD, D.; CARDNO, C.E.M. (2001). Managing teacher appraisal and performance: $A$ comparative approach. London: RoutledgeFalmer.

MILES, K.H.; DARLING-HAMMOND, L. (1998). Rethinking the allocation of teaching resources: Some lessons from high-performing schools. Educational Evaluation and Policy Analysis, 20(1): 9-29. http://dx.doi.org/10.3102/01623737020001009

MILGROM, P.; ROBERTS, J. (1992). Economics, organization and management. Englewood Cliffs, NJ: Prentice Hall.

MILKOVICH, T.G.; BOUDREAU, W.J. (1998). Human resource management (8th ed.). Boston: Irwin.

MORELAND, R.X.; LEVINE, J.M. (2001). Socialization in organizations and workgroups. In M. Turner (Ed.), Groups at work: Theory and research (pp. 69-112). Mahwah, NJ: Earlbaum.

MOSTELLER, F. (1995). The Tennessee study of class size in the early school grades. The Future of Children, 5(2): 113-127. http://dx.doi.org/10.2307/1602360

OSTERMAN, P. (1987). Turnover, employment security, and the performance of the firm. In M.M. Kleiner, R.N. Block, M. Roomkin \& S.W. Salsburg (Eds.), Human resources and firm performance. Washington DC: BNA Press.

OSTROFF, C. (1992). The relationship between satisfaction, attitudes, and performance: An organizational level analysis. Journal of Applied Psychology, 77(6): 963-974.

http://dx.doi.org/10.1037/0021-9010.77.6.963

OTTENBACHER, M.; GNOTH, J.; JONES, P. (2006). Identifying determinants of success in development of new high-contact services: Insights from the hospitality industry. International Journal of Service Industry Management, 17(4): 344-363.

http://dx.doi.org/10.1108/09564230610680659 
PAAUWE, J. (2004). HRM and performance: Achieving long-term viability. New York: Oxford University Press Inc. http://dx.doi.org/10.1093/acprof:0so/9780199273904.001.0001

PAAUWE, J.; BOSELIE, P. (2005). HRM and performance: What next?. Human Resource Management Journal, 15(4): 68-83. http://dx.doi.org/10.1111/j.1748-8583.2005.tb00296.x

PAAUWE, J. (2009). HRM and performance: Achievements, methodological issues and prospects. Journal of Management Studies, 46(1): 129-141. http://dx.doi.org/10.1111/j.14676486.2008.00809.x

PANAYOTOPOULOU, L.; BOURANTAS, D.; PAPALEXANDRIS, N. (2003). Strategic human resource management and its effects on firm performance: An implementation of the competing values framework. International Journal of Human Resource Management, 14(4): 680-699. http://dx.doi.org/10.1080/0958519032000057781

PENNINGS, J.M.; LEE, K.; VAN WITTELOOSTUIJN, A. (1998). Human capital, social capital, and firm dissolution. Academy of Management Journal, 41(4): 425-440.

http://dx.doi.org/10.2307/257082

PFEFFER, J. (1994). Competitive advantage through people: Unleashing the power of the workforce. Boston: Harvard Business School Press.

PORTER, L.W.; STEERS, R.M.; MOWDAY, R.T.; BOULIN, P.V. (1974). Organizational commitment, job satisfaction, and turnover among psychiatric technicians. Journal of Applied Psychology, 59(5): 603-609. http://dx.doi.org/10.1037/h0037335

PURCELL, J.; HUTCHINSON, S.; KINNIE, N.; RAYTON, B.; SWART, J. (2003). Understanding the pay and performance link: Unlocking the black box. London: CIPD.

REYNOLDS, D. (Ed.). (1985). Studying school effectiveness. London: Palmer Press.

RUMBERGER, R.W.; THOMAS, S.L. (2000). The distribution of dropout and turnover rates among urban and suburban high schools. Sociology of Education, 73(1): 39-67. http://dx.doi.org/10.2307/2673198

SAEED, M.; GONDAL, M.B.; BUSHRA, W. (2005). Assessing primary grade students and factors affecting achievement in Pakistan. International Journal of Educational Management, 19(6): 486-499. http://dx.doi.org/10.1108/09513540510617436

SALAMON, L.M. (1991). Overview: Why human capital? Why now?. In D.W. Hornbeck \& L.M. Salamon (Eds.), An economic strategy for the 90s; human capital and America's future (pp. 1-39). Baltimore: Johns Hopkins University Press.

SANDER, W. (1999). Endogenous expenditures and student achievement. Economics Letters, 64(2): 223-231. http://dx.doi.org/10.1016/S0165-1765(99)00083-X 
SAVANEVICIENE, A.; STANKEVICIUTE, Z. (2010). The models exploring the "black box" between HRM and organizational performance. Inzinerine Ekonomika-Engineering Economics, 21(4): 426-434.

SCHNEIDER, J.M.; GLASHEEN, J.D.; HADLEY, D.W. (1979). Secondary school participation, institutional socialization, and student achievement. Urban Education, 14(3): 285-302. http://dx.doi.org/10.1177/0042085979143002

SCHULER, R.S.; MACMILLAN, I. (1984). Gaining competitive advantage through human resource practices. Human Resource Management, 23(3): 241-255.

http://dx.doi.org/10.1002/hrm.3930230304

SCHULER, R.S.; JACKSON, S.E. (1987). Linking competitive strategies with human resource management practices. Academy of Management Executive, 1(3): 207-219.

http://dx.doi.org/10.5465/AME.1987.4275740

SCRIBNER, J.P.; SMYLIE, M.A.; MOSLEY, H.L. (2008). District workforce development and instructional capacity: A strategic perspective. Paper presented at the American Educational Research Association Conference.

SHORE, L.M.; TETRICK, L.E.; TAYLOR, M.S.; COYLE-SHAPIRO, J.; LIDEN, R.; MCLEAN-PARKS, J.; et al. (2004). The employee-organization relationship: A timely concept in a period of transition. In J. Martocchio (Ed.), Research in personnel and human resources management (23: 291-370). Greenwich, CT: JAI Press.

SINGH, S.; DARWISH, T.K.; COSTA, A.C.; ANDERSON, N. (2012). Measuring HRM and organisational performance: Concepts, issues, and framework. Management Decision, 50(4): 651-667. http://dx.doi.org/10.1108/00251741211220282

SMITH, M.A. (2001). The relationship between student-teacher ratio and academic readiness in West Virginia preschool programs. Huntington, WV: Marshall University.

SMITHER, J.W.; LONDON, M.; VASILOPOULOS, N.X.; REILLY, R.R.; MILLSAP, R.E.; SALVEMINI, N. (1995). An examination of the effects of an upward feedback program overtime. Personnel Psychology, 48(1): 1-34. http://dx.doi.org/10.1111/j.1744-6570.1995.tb01744.x

SOYIBO, K.; JOHNSON, R. (1998). Science knowledge, science attitudes and self-esteem: A comparison of rose and nonrose grades 7 and 8 students. Caribbean Journal of Education, 19(2): 163-178.

STOCKHAUSEN, N.; SOYIBO, K. (2004). Relationships among Jamaican ninth-graders' variables and performance in integrated science. Journal of Science and Mathematics Education in Southeast Asia, 27(2): 262-280. 
SUN, L.; ARYEE, S.; LAW, K.S. (2007). High-performance human resource practices, citizenship behavior, and organizational performance: A relational perspective. Academy of Management Journal, 50(3): 558-577. http://dx.doi.org/10.5465/AMJ.2007.25525821

SURYADARMA, D.; SURYAHADI, A.; SUMARTO, S.; ROGERS, F.H. (2006). Improving student performance in public primary schools in developing countries: Evidence from Indonesia. EDUCATION ECONOMICS, 14(4): 401-429. http://dx.doi.org/10.1080/09645290600854110

TAMKIN, P. (2004). High performance work practices. Brighton: Institute for Employment Studies.

ULRICH, D. (1991). Using human resources for competitive advantage. In R. Kilmann \& I. Kilmann Associates (Eds.), Making organizations competitive. San Francisco: Jossey-Bass.

VERBURG, R.M. (1998). Human resource management: Optimale HRM-praktijken en configuraties. Amsterdam: Vrije Universiteit.

VERMA, A. (1995). Employee involvement in the workplace. In M. Gunderson \& A. Ponak (Eds.), Research in personnel and human resource management. New Haven, CT: JAI Press.

VON SECKER, C. (2004). Science achievement in social contexts: Analysis from national assessment of educational progress. The Journal of Educational Research, 98(2): 67-78. http://dx.doi.org/10.3200/JOER.98.2.67-78

VROOM, V.; JAGO, A.G. (1988). The new leadership: Managing participation in organizations. Englewood Cliffs, NJ: Prentice Hall.

WAGNER, J.A. (1994). Participation's effect on performance and satisfaction: A reconsideration of research evidence. Academy of Management Review, 19(2): 312-330.

WALKER, A.G.; SMITHER, J.W. (1999). A five-year study of upward feedback: What managers do with their results matters. Personnel Psychology, 52(2): 393-423.

http://dx.doi.org/10.1111/j.1744-6570.1999.tb00166.x

WALL, T.D.; WOOD, S.J. (2005). The romance of human resource management and business performance, and the case for big science. Human Relations, 58(4): 429-462. http://dx.doi.org/10.1177/0018726705055032

WAY, S.A. (2002). High performance work systems and intermediate indicators of firm performance within the US small business sector. Journal of Management, 28(6): 765-785. http://dx.doi.org/10.1016/S0149-2063(02)00191-5

WEBB, L.D.; NORTON, M.S. (2009). Human resources administration: Personnel issues and needs in education. Upper Saddle River, NJ: Merrill. 
WEI, L.; LAU, C. (2010). High performance work systems and performance: The role of adaptive capability. Human Relations, 63(10): 1487-1511.

http://dx.doi.org/10.1177/0018726709359720

WILLIAMS, J.E. (1996). Promoting rural students' academic achievements: An examination of self-regulated learning strategies. Paper presented at The Annual Meeting of the American Educational Research Association, New York.

WRIGHT, P.; MCMAHAN, G.; McWILLIAMS, A. (1994). Human resources and sustained competitive advantage: A resource based perspective. International Journal of Human Resource Management, 5(2): 301-326. http://dx.doi.org/10.1080/09585199400000020

WRIGHT, P.; BOSWELL, W. (2002). Desegregating HRM: A review and synthesis of micro and macro human resource management research. Journal of Management, 28(3): 247-276. http://dx.doi.org/10.1177/014920630202800302

WRIGHT, P.; GARDNER, T. (2003). Theoretical and empirical challenges in studying the HR practice - firm performance relationship. In D. Holman, T.D. Wall, C. Clegg, P. Sparrow \& A. Howard (Eds.), The new workplace: $A$ guide to the human impact of modern working practices (pp. 311-330). New York: John Wiley and Sons.

WRIGHT, P.M.; SNELL, S.A. (1991). Toward an integrative view of strategic human resource management. Human Resource Management Review, 1(3): 203-225.

http://dx.doi.org/10.1016/1053-4822(91)90015-5

WRIGHT, P.M.; MCMAHAN, G.C. (1992). Theoretical perspectives for strategic human resource management. Journal of Management, 18(2): 295-320.

http://dx.doi.org/10.1177/014920639201800205

WRIGHT, P.M.; MCMAHAN, G.C.; SNELL, S.A.; GERHART, B. (2001a). Comparing line and HR executives' perceptions of HR effectiveness: Services, roles, and contributions. Human Resource Management, 40(2): 111-123. http://dx.doi.org/10.1002/hrm.1002

WRIGHT, P.M.; GARDNER, T.M.; MOYNIHAN, L.M.; PARK, H.J.; GERHART, B.; DELERY, J.E. (2001b). Measurement error in research on human resources and firm performance: Additional data and suggestions for future research. Personnel Psychology, 54(4): 875-901. http://dx.doi.org/10.1111/j.1744-6570.2001.tb00235.x

WRIGHT, P.M.; DUNFORD, B.; SNELL, S. (2001c). Human resources and the resource based view of the firm. Journal of Management, 27(6): 701-721.

http://dx.doi.org/10.1177/014920630102700607

WRIGHT, PM.; GARDNER, T.; MOYNIHAN, L. (2003). The impact of human resource practices on business unit operating and financial performance. Human Resource Management Journal, 13(3): 21-36. http://dx.doi.org/10.1111/j.1748-8583.2003.tb00096.x 
WRIGHT, P.M.; GARDNER, T.M.; MOYNIHAN, L.M.; ALLEN, M.R. (2005). The relationship between HR practices and firm performance: Examining causal order. Personnel Psychology, 58(2): 409-446. http://dx.doi.org/10.1111/j.1744-6570.2005.00487.x

WRIGHT, P.M.; NISHII, L.H. (2006). Strategic HRM and organizational behaviuor: Integrating multiple levels of analysis. CITY: Cornell University.

YOUNDT, M.A.; SNELL, S.A.; DEAN, J.W.; LEPAK, D.P. (1996). Human resource management, manufacturing strategy, and performance. Academy of Management Journal, 39(4): 836866. http://dx.doi.org/10.2307/256714

YOUNDT, M.A.; SNELL, S.A. (2004). Human resource configurations, intellectual capital, and organizational performance. Journal of Managerial Issues, 16(3): 337-360.

YOUNG, D.J. (1998). Rural and urban differences in student achievement in science and mathematics: A multilevel analysis. School Effectiveness and School Improvement, 9(4): 386-418. http://dx.doi.org/10.1080/0924345980090403

YOUNG, I.P. (2008). The human resource function in educational administration (5th ed.). Upper Saddle River, NJ: Merill.

Intangible Capital, 2014 (www.intangiblecapital.org) 